\title{
Organophosphorous pesticides and estrogen induce transformation of breast cells affecting p53 and $\mathrm{c}$-Ha-ras genes
}

\author{
GLORIA M. CALAF ${ }^{1,2}$, CARLOS ECHIBURU-CHAU $^{1}$ and DEBASISH ROY ${ }^{3}$ \\ ${ }^{1}$ Instituto de Alta Investigación, Universidad de Tarapacá, Arica, Chile; ${ }^{2}$ Center for Radiological Research, \\ Columbia University Medical Center, New York; ${ }^{3}$ Department of Natural Sciences, \\ Hostos College of the City University of New York, Bronx, NY, USA
}

Received June 2, 2009; Accepted August 6, 2009

DOI: 10.3892/ijo_00000421

\begin{abstract}
Cancer progression has been associated with an increase in genomic instability indicated by inactivation of tumor suppressor genes and activation of oncogenes. Epidemiological and experimental evidence has implicated estrogens in the etiology of breast cancer. To study environmental organophosphorous pesticides is of interest since evidence indicate that pesticides may enhance cell division, increasing the risk of breast cancer. The aim was to evaluate the effects of these pesticides, such as parathion and malathion in the presence of estrogen on malignant transformation as well as on genomic instability, that is in the frequency of loss of heterozygosity (LOH) and microsatellite instability (MSI). The MCF-10F immortalized human breast epithelial cell line, that was treated with parathion or malathion alone and in combination with estrogen was used. These studies indicated that either pesticide alone or in combination with estrogen induced malignant transformation as shown by anchorageindependent growth capability and invasive characteristics in comparison to control. Such malignant phenotypic characteristics were corroborated by significant $(\mathrm{P}<0.05)$ increase in $\mathrm{p} 53$ and c-Ha-ras protein expression. Results indicated different degrees of allelic imbalance in the form of LOH or MSI with different microsatellite markers. MSI was found in malathion and estrogen-treated cells with a marker used for p53 tumor suppressor gene at loci $17 \mathrm{p} 13.1$. The same combination of substances presented MSI with a marker used for c-Ha-ras mapped in chromosome $11 \mathrm{p} 14.1$, as well as mutations in c-Ha-ras for codons 12 and 61. LOH was observed in codon 12 in the presence of estrogen or malathion alone. Parathion
\end{abstract}

Correspondence to: Dr Gloria M. Calaf, Instituto de Alta Investigación, Universidad de Tarapacá, Calle Antofagasta \#1520, Arica, Chile

E-mail: gmc24@columbia.edu

Key words: c-Ha-ras, breast cells, organophosphorous pesticides, estrogen alone and combined with estrogen induced MSI in codon 61 . It can be concluded that the organophosphorous pesticides parathion and malathion induced malignant transformation of breast cells through genomic instability altering p53 and c-Ha-ras, considered pivotal to cancer process.

\section{Introduction}

Breast cancer is the most common form of cancer among women. Environmental chemicals and endogenous factors seem to be involved in the etiology of this disease. There has been continued interest in environmental contaminants that may play a role in breast cancer risk (1). Organophosphorous pesticides, such as parathion and malathion have been extensively used to control mosquito plagues $(2,3)$. Whether exposure to agricultural pesticide applications is related with breast cancer incidence in women is an unsolved question (4). Pesticides have been of great interest in etiologic breast cancer studies due to the fact that many pesticides or their metabolites mimic estrogen, which is known to increase breast cancer risk (5-7). Epidemiological and experimental evidence has implicated estrogens in the etiology of breast cancer $(8,9)$. Among these hormonal influences a leading role is attributed to estrogen since prolonged stimulation by steroid hormones may increase cell division, increasing the risk of breast cancer $(8,10,11)$.

p53 has been identified as an important tumor suppressor gene in normal cells (12-14). It has been reported that early loss of cell-cycle control in the presence of a mitogenic stimulus allows a cell to continue dividing (13). Wild-type p53 plays a crucial role in maintaining genomic stability by allowing the repair of damaged DNA through induction of a transient G1 arrest or eliminating the damaged cells by triggering apoptosis (12). Mutant p53 (mp53) fails to mediate any of these effects. Uncontrolled proliferation in the absence of wild-type $p 53$ would expectedly yield a high level of genomic instability, which is a common abnormality detected in primary breast cancer $(12,14)$. Wild-type $p 53$ is a recessive tumor suppressor gene, located on chromosome 17p13 (15) and it has been implicated in the control of cell cycle, DNA repair and synthesis, differentiation and apoptosis. After DNA damage normal cells stop in $\mathrm{G} 1 / \mathrm{S}$ to allow time for repair. 
mp53 act as dominant oncogene and cells with alteration in the $p 53$ gene do not stop in G1/S. Thus, DNA damage is not repaired and genomic instability appears with accumulation of deletions and amplifications $(16,17)$. The $m p 53$ has been found in $20-50 \%$ of human cancers (17).

The activation of oncogenes promotes cell growth and survival. Transforming genes of Harvey and Kirsten murine sarcoma viruses are three closely-related genes, $c-H$-ras, $K$ ras, $N$-ras, expressed in mammalian cells (18). The incidence of ras mutation varies between different types of cancer and appears to occur early in the multi-step process. Mutated ras genes occur with a high frequency in common human cancers, including adenocarcinoma of the lung, colorectal cancer, myeloid leukemia, adenocarcinoma of the pancreas $(18,19)$. The expression of ras proto-oncogenes in relation to regulation and implications of the genes was analyzed in the development of human tumors and they summarized and discussed experimental results concerning the regulatory mechanisms involved in oncogenic transformation.

Activated $c$-Ha-ras genes, mapped to 11 p15.5 (20), containing single substitutions in particular positions in the gene locus has been found in $\sim 10 \%$ of human cancers examined $(21,22)$. The mutation responsible for the gene activation was located in codons $12,13,61$ or $17(21,22)$. Activated $\mathrm{Ki}$-, $\mathrm{c}$-Ha- and $\mathrm{N}$-ras, all with a point mutation in codons 12,13 and 61 , but 12 and 61 mutation are more pronounced compared to codon 13 (23). Elevated expression of the Harvey ras oncogene was reported in human malignant tumors of the breast as compared to their respective normal tissue (24).

In general, the activation of oncogenes and inactivation of tumor suppressor genes underlie carcinogenesis, and tumors develop through an accumulation of several genetic alterations. Loss of heterozygosity ( $\mathrm{LOH}$ ) is a change from a heterozygous to a homozygous state due to loss of the wild-type allele. Many studies have revealed that $\mathrm{LOH}$ at chromosome bands $1 \mathrm{p} 36$, 3p24-p25, 6q12-q16, 11p15, 11q22, 11q23, 13q21, 16q22, $17 \mathrm{p} 21$, and $17 \mathrm{q} 25$, plays important roles in breast cancer, and these genetic alterations have complex interactions (25-27). Microsatellite instability (MSI) was formerly known as replication error phenotype or ubiquitous somatic mutations. It is defined as an alteration in the microsatellite sequence length within tumor DNA when compared with normal DNA from an individual (28-30). MSI can be detected by demonstration of variability in the number of repeat units in selected microsatellite markers following amplification using polymerase chain reaction (PCR) between tumor and normal DNA (28). Microsatellite marker analysis has been used extensively to detect evidence of defective repair of DNA synthesis errors (31).

Cancer occurs at molecular level due to gene alterations. The passage from one pathologic lesion to another has been associated with different genetic events, including an overall increase in genomic instability as inactivation of tumorsuppressor genes (p53) and activation of oncogenes ( $c$ - $H$-ras) (32). The present study evaluated the effect of two organophosphorous pesticides, parathion and malathion in combination with estrogen assessing the genomic instability of p53 and $c$-H-ras in MCF-10F, a spontaneously immortalized human breast epithelial cell line.

\section{Materials and methods}

Cells. MCF-10F cell line (33) used in these studies was maintained in culture media as described previously (34-36). The cells used in these experiments were: 1) MCF-10F (control); 2) MCF-10F continually treated with 173 estradiol (E) $\left(10^{-8} \mathrm{M}\right)$ (Sigma-Aldrich, St. Louis, MO); MCF-10F cells treated continuously with 3$)$ parathion (P) $(100 \mu \mathrm{l} / \mathrm{ml})$ (parathion-ethyl); 4) parathion in combination with estrogen (PE); 5) malathion (2 $\mu \mathrm{l} / \mathrm{ml})(\mathrm{M})$; and 6) malathion in combination estrogen (ME). Previous studies (37) indicated that $17 ß$ estradiol at $10^{-8} \mathrm{M}$ dissolved in the culture media was the best stimulatory dose when analyzed from $10^{-6}$ to $10^{-10} \mathrm{M}$. The cell line named Alpha5, a tumorigenic cell line was used in this study for comparative purpose and it derives from an established in vitro human breast cancer epithelial cell line model (35). MCF-10F cells was treated with 60 cGy dose of $\alpha$ particles followed by estrogen treatment and exposed to a second dose of $60 \mathrm{cGy}$ of $\alpha$ particles followed by estrogen $(60 c G y+E / 60 c G y+E)$.

Cell transformation assays. To test for cell growth in semisolid medium anchorage-independent assay was carried out with cells in passage 20 after the treatments as previously described (35). After 2 weeks of incubation, colonies with $>50$ cells were counted under a dissecting microscope and the cloning efficiency was determined. Cell invasion assay was carried out using modified Boyden's chambers (Transwell; Costar, Cambridge, MA). The total number of cells that crossed the membrane was counted under a light microscope (34).

Quantification of protein expression. mp53 and c-Ha-Ras protein expression was assessed by immunofluorescent technique coupled with confocal microscopy as previously described $(34,36,37)$. Quantification of protein expression was performed with a computational program. For Western blot hybridization analyses, whole-cell protein extracts were prepared (38) and antibodies against mp53 (sc-99) and $\mathrm{c}-\mathrm{Ha}$ Ras (sc-29) (both from Santa Cruz Biotechnology) were used in these studies. A secondary horseradish peroxidase-coupled anti-mouse was used to detect immunodetection of proteins. The chemiluminescent immunoblotting system ECL kit (Amersham Life Sc., IL) was used for detection and results were quantified by scanning the blots with a densitometer.

DNA isolation. Control and treated cells were extracted and purified according to standard procedure (38). All cell cultures were treated with $1 \mathrm{ml}$ lysis buffer $(100 \mathrm{mM} \mathrm{NaCl}, 20 \mathrm{mM}$ Tris- $\mathrm{HCl} \mathrm{pH} 8.0,25 \mathrm{mM}$ EDTA, $\mathrm{pH} 8.0,0.5 \%$ SDS) with $200 \mathrm{mg} / \mathrm{ml}$ proteinase $\mathrm{K}$ and $100 \mu \mathrm{g} / \mathrm{ml}$ RNAase and incubated overnight at $37^{\circ} \mathrm{C}$ with constant gentle agitation (39). Then there were two extractions with a phenol 1: chloroform (1:1) mixture and the aqueous layer was adjusted to $0.75 \mathrm{M}$ ammonium acetate and DNA was spooled from 2 volumes of $100 \%$ ethanol, dried and dissolved in TE buffer $(10 \mathrm{mM}$ Tris- $\mathrm{HCl} \mathrm{pH}$ 8.0, 1 mM EDTA pH 8.0) as described (38).

Microsatellite polymorphic marker selection. Polymorphic dinucleotide (CA) n repeat microsatellite markers (Research Genetics, Huntsville, AL) were selected on the basis of their 
Table I. Microsatellite polymorphic marker selection.

A, Oligonucleotide primers for PCR amplification of microsatellite markers for $p 53$ and $c$-Ha-ras

\begin{tabular}{lcccc}
\hline Locus & $\begin{array}{c}\text { Map } \\
\text { position }^{\mathrm{a}}\end{array}$ & $\begin{array}{c}\text { Maximum } \\
\text { heterozygosity }\end{array}$ & $\begin{array}{c}\text { Type of } \\
\text { sequence }\end{array}$ & $\begin{array}{c}\text { Size range } \\
\text { base pairs }\end{array}$ \\
\hline TP53 & $17 \mathrm{p} 13.1$ & 0.90 & Dinucleotide & $103-135$ \\
HRAS1 & $11 \mathrm{p} 15.5$ & 0.90 & Dinucleotide & $244-261$ \\
\hline
\end{tabular}

B, Primers selected to amplify microsatellite sequences for $c$-Ha-ras and p53 studies, listed in a $5^{\prime} \rightarrow 3^{\prime}$ orientation

Primer name

Primer sequence

\begin{tabular}{ll}
\hline TP53 & ATCTACAGTCCCCCTTGCCG/ \\
& GCAACTGACCGTGCAAGTCA \\
HRAS1 & TCACTGACCCTCTCCCTTGACACAG/ \\
& TCATGCTACAGCAGCCCCTCAAAGG \\
\hline
\end{tabular}

aPrecise location of markers on respective chromosome arms.

maximum heterozygosity $(>0.70)$ and their location near mapped, p53 and c-Ha-ras (Table IA). The sequences and characteristics of microsatellite oligonucleotide primers were obtained from the GDB database (Table IB).

Mutations studies in codons 12 and 61 of c-Ha-ras. To determine whether organophosphorous and estrogen treatment resulted in point mutations in $\mathrm{c}$-Ha-ras codons 12 and 61, cells were studied by direct sequencing of the amplified $c$-Ha-ras oncogene. The Exon 1 of the $c$-Ha-ras oncogene was amplified with forward (5'-CGA TGA CGG AAT ATA AGC TTG TGG TGGT-3') and reverse (5'-GTT CAC CTG TAC TGG TGG AAT TCC TCA AA-3') primers (Life Technologies, Inc., Grand Island, NY) to obtain the 545-bp PCR product for codon 12. Similarly, Exon 1 was amplified with forward (5'-ACG CCT GTC CTC CTG CAA GCT TCC TAC-3') and same reverse primers (Life Technologies, Inc.) to produce the 202-bp PCR product for codon 61. DNA amplifications were carried out in a PCR reaction volume of $30 \mu$ l containing 50-100 ng of genomic DNA, $1.5 \mathrm{mM} \mathrm{MgCl}_{2}, 50 \mathrm{mM} \mathrm{KCl}$, $10 \mathrm{mM}$ Tris- $\mathrm{HCl}$ (pH 8.3), $200 \mu \mathrm{M}$ of each dNTPs, $0.8 \mu \mathrm{M}$ of each primer (Life Technologies, Inc.) and $0.75 \mathrm{U}$ of AmpliTaq polymerase (Perkin-Elmer Corp., Foster City, CA). The genomic DNA was initially denatured for a 5-min pre-incubation period at $95^{\circ} \mathrm{C}$ and thereafter subjected to 35 cycles comprising of denaturation at $94^{\circ} \mathrm{C}$ for $45 \mathrm{sec}$, annealing at $60^{\circ} \mathrm{C}$ for $1 \mathrm{~min}$ and extension for $1 \mathrm{~min}$ at $65^{\circ} \mathrm{C}$, followed by a 7 -min final extension at $65^{\circ} \mathrm{C}$ using the GeneAmp PCR System 2400 (Perkin-Elmer Corp.) (20,40).

Direct sequencing of amplified DNA fragments. Sequencing was carried out on original PCR products amplified by using the same $c$-Ha-ras codon 12 and 61 primers. PCR products were gel purified by electrophoresis on $1 \%$ agarose-TAE gel
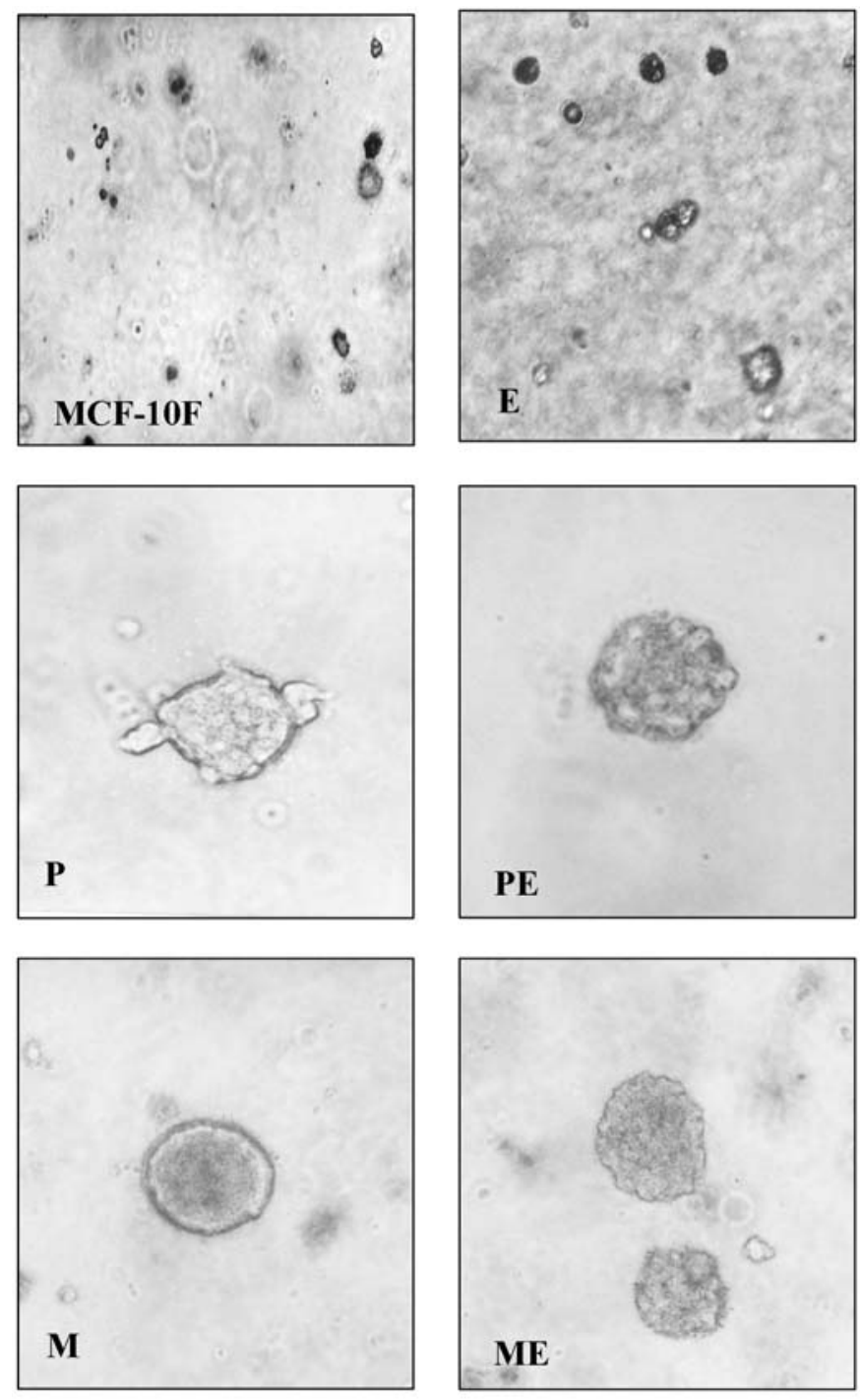

Figure 1. Representative images of anchorage-independency assay. Colony formation of MCF-10F-, E-, P-, PE-, and ME-treated cells.

(Life Technologies Inc.) and eluted with $100 \mu 1$ of elution buffer of QIAquick gel extraction kit (Qiagen Inc., CA). Sequencing was done by using automated sequencer ABI PRISM 3100 genetic analyzer (Applied Biosystems/Hitachi, Foster City, CA). Each fragment was sequenced at least three times to rule out contamination and PCR fidelity artifacts.

\section{Results}

This study analyzed the effects in vitro of parathion and malathion, two organophosphorous pesticides, in combination with estrogen on cell transformation and genomic instability of MCF-10F. Phenotypic characteristics were assessed to determine malignant transformation of cells. These results indicated that P-, M-, PE- and ME-treated-cells were positive to anchorage-independent growth capability. The P-, M-, PE- and ME-treated cells formed agar-positive clones efficienly in $1 \%$ agar. The control and E-treated cells were unable to form colonies. Representative images of 


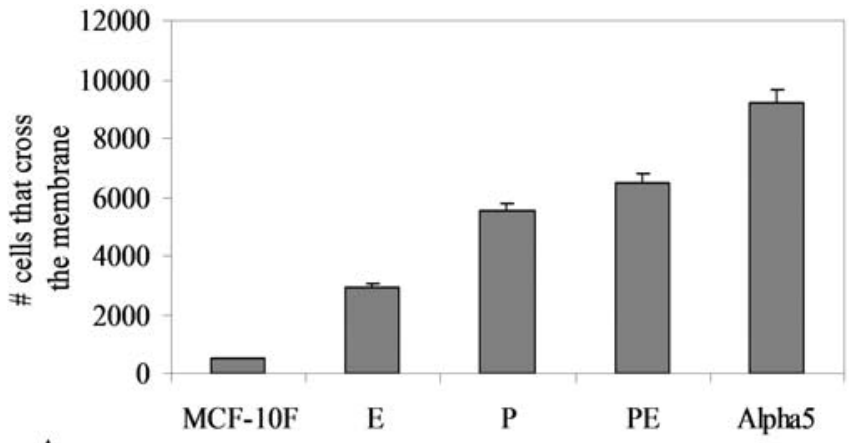

A

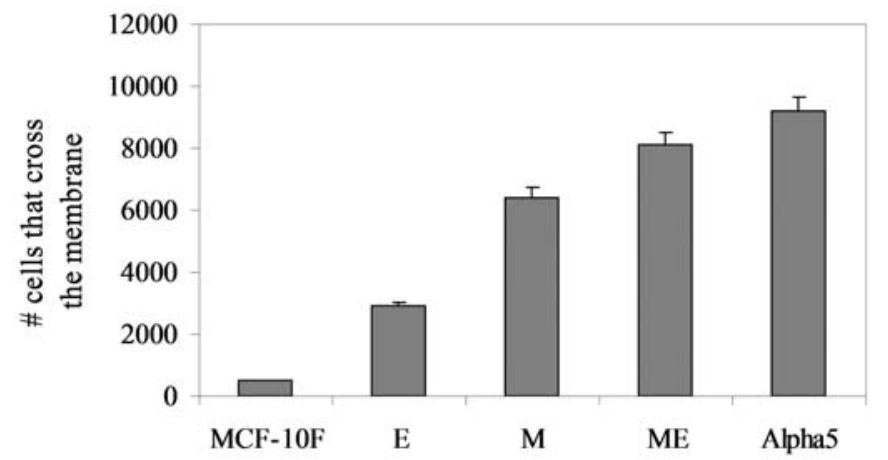

B

Figure 2. Invasive characteristics of (A) MCF-10F-, E-, P-, PE- and Alpha5treated cells and (B) MCF-10F-, E-, M-, ME- and Alpha5-treated cells. Bars represent $\pm \mathrm{SD}(\mathrm{p}<0.01)$.

anchorage-independent growth of MCF-10F, E-, P-, M-, PEand ME- treated cells are shown in Fig. 1.

Invasive capability of MCF-10F, E-, P-, M-, PE- and MEtreated cells and Alpha5 cell line are shown in Fig. 2A and B. Results indicated that P- and PE-treated cells had greater $(\mathrm{P}<0.05)$ invasive capability than control and either control or E-treated cells alone according to the number of cells that crossed the membranes (Fig. 2A). ME-treated cells had greater $(\mathrm{P}<0.05)$ invasive capability than control and either E- or M-treated cells according to the number of cells that crossed the membranes (Fig. 2B). The tumorigenic cell line Alpha5 had greater invasive capabilities than the combination of PE- and ME-treated cells.

Fig. 3A and B show the representative immunofluorescent images of confocal microscopy of mp53 and $\mathrm{c}$-Ha-ras protein expression of MCF-10F, E-, P-, PE-treated cells and Alpha5 cell line. A significant $(\mathrm{P}<0.05)$ increase in protein expression was observed in PE-treated cells and Alpha5 cell line in comparison to MCF-10F or E-treated cells alone. Quantification of mp53 and $c$-Ha-ras protein expression detected by Western blot can be seen in Fig. 4A and B. Mutant p53 protein expression was significantly $(\mathrm{P}<0.05)$ increased in PE-treated cells in comparison to control or either E- or Ptreated cells (Fig. 4A). Alpha5 cell line had similar protein expression to PE-treated cells. The c-Ha-ras protein expression was significantly $(\mathrm{P}<0.05)$ increased in PE-treated cells in comparison to control or either E- or P-treated cells (Fig. 4B). There was not significant difference between control and parathion-treated cell lines; however, PE-treated Alpha5 cell line had similar protein expression.

Different degrees of allelic imbalance in the form of $\mathrm{LOH}$ or MSI with different microsatellite markers are shown in Fig. 5A-D. Fig. 5A shows MSI in ME-treated cells with a marker used for $p 53$ tumor suppressor gene at loci $17 \mathrm{p} 13.1$. The marker used for $\mathrm{c}$-Ha-ras mapped in chromosome 11p14.1 showed MSI in ME-treated cells (Fig. 5B). Mutations in $\mathrm{c}$-Ha-ras for codons 12 and 61 can be seen in Fig. 5C and D. Fig. 5C showed LOH in genomic DNA for codon 12 in the E- and M-treated cells. Fig. 5D showed MSI in genomic DNA for codon 61 for P- and PE-treated cells and LOH for M-treated cells.

\section{Discussion}

In the 1980s, the International Agency for Research on Cancer conducted evaluations of the literature to assess the potential human carcinogenicity of malathion, concluding that there was limited evidence for the mutagenicity of malathion $(41,42)$. Malathion or its metabolite malaoxon was not mutagenic in several Salmonella strains $(43,44)$. The findings of both in vitro and in vivo studies of cytogenetic changes in humans and other mammals have been inconsistent (45-48). Some in vivo studies demonstrated that parathion and malathion results in disruption of endocrine system. Inhibition of progesterone secretion and poor conception occurred after malathion exposure at the onset of estrus in cattle (49).

Other studies showed significant disturbance in the ovarian cycle after treatment of rats with methyl parathion in the variability of the number of estrus cycles and the duration of each phase of the estrus cycle $(50,51)$. The pesticide malathion gave similar results (52). In epidemiological studies malathion did not appear to be associated with increased risk for any of the cancers examined (53). However, other experimental evidence suggests that malathion or its derivatives may be carcinogenic. Blasiak et al (54) showed that malaoxon and isomalathion induced DNA damage. Both malaoxon and isomalathion are impurities found in commercial-grade malathion (55).

These studies indicated that the pesticide organophosphorous, either parathion or malathion, in combination with estrogen induced malignant phenotype of breast cells in vitro. However, only the combination of these organophosphorous and estrogen induced genomic instability as indicated by loss of heterozygosity and microsatellite instability considered pivotal to tumor growth. The phenotypic characteristics of parathion alone or parathion combined with estrogen, malathion, and combination of malathion and estrogen-treated cells were assessed to determine malignant transformation. Such cell lines formed agar-positive clones and had greater invasive capability than control and estrogen-treated cells. Analysis of mp53 and c-Ha-ras protein expression showed an increase in parathion and estrogen-treated cells similar to the tumorigenic cell line Alpha5 in comparison to control or estrogen-treated cells. We (36) previously showed an increase in mutant p53 oncoproteins in MCF-10F cells irradiated with a double dose of $\alpha$-particles either in the presence or absence of estrogen and in a tumorigenic cell line in comparison with control MCF-10F cell line. These could be associated with a 

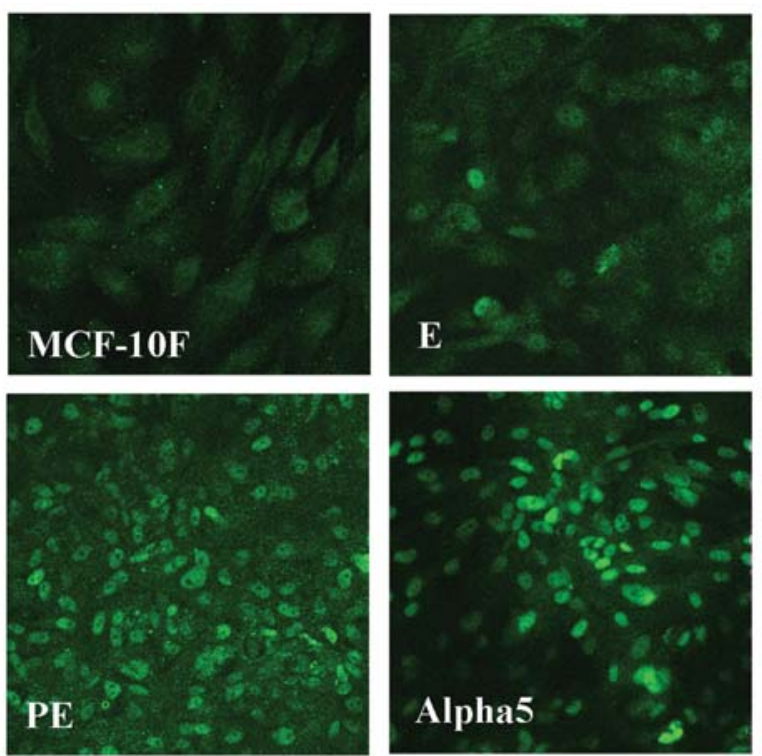

A
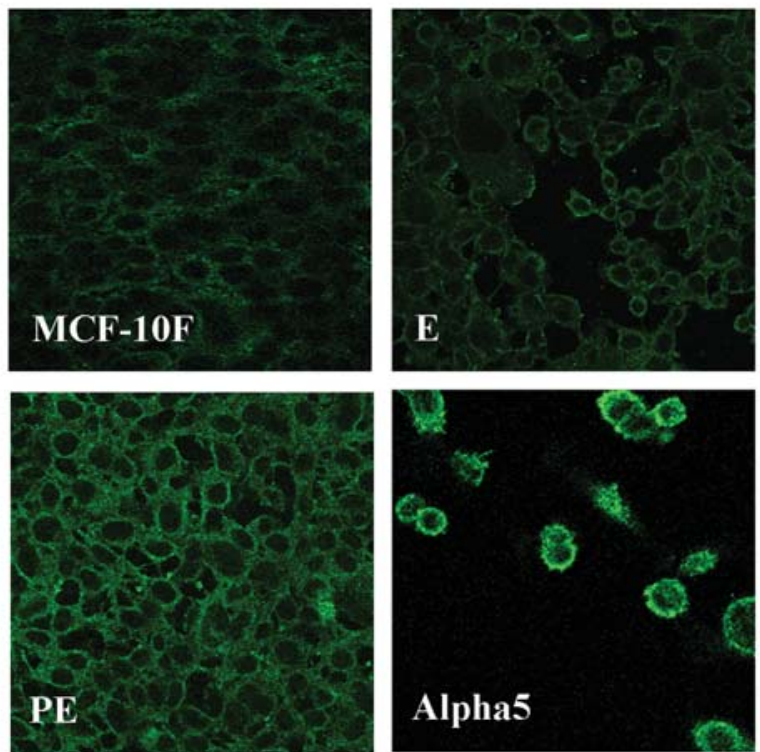

B

Figure 3. Representative images and quantification of protein expression done with immunofluorescence with confocal microscopy coupled with a computational program. (A) mp53 protein expression and (B) c-Ha-ras protein expression.

loss of control over DNA replication or mitotic errors and give rise to a further cascade of mutations. Previous studies (56) have shown that cells treated with parathion or malathion in combination with estrogen exhibited increased mutant p53, Rho-A, Rac-3, ß-catenin, epidermal growth factor receptor (EGFR), among others in comparison to control MCF-10F cell line when differential expression was analyzed with cDNA arrays.

Different degrees of allelic imbalance in the form of microsatellite instability with different microsatellite markers are reported in the present study. The combination of malathion and estrogen induced microsatellite instability with a marker used for $p 53$ tumor suppressor gene at loci 17p13.1. Aberrant
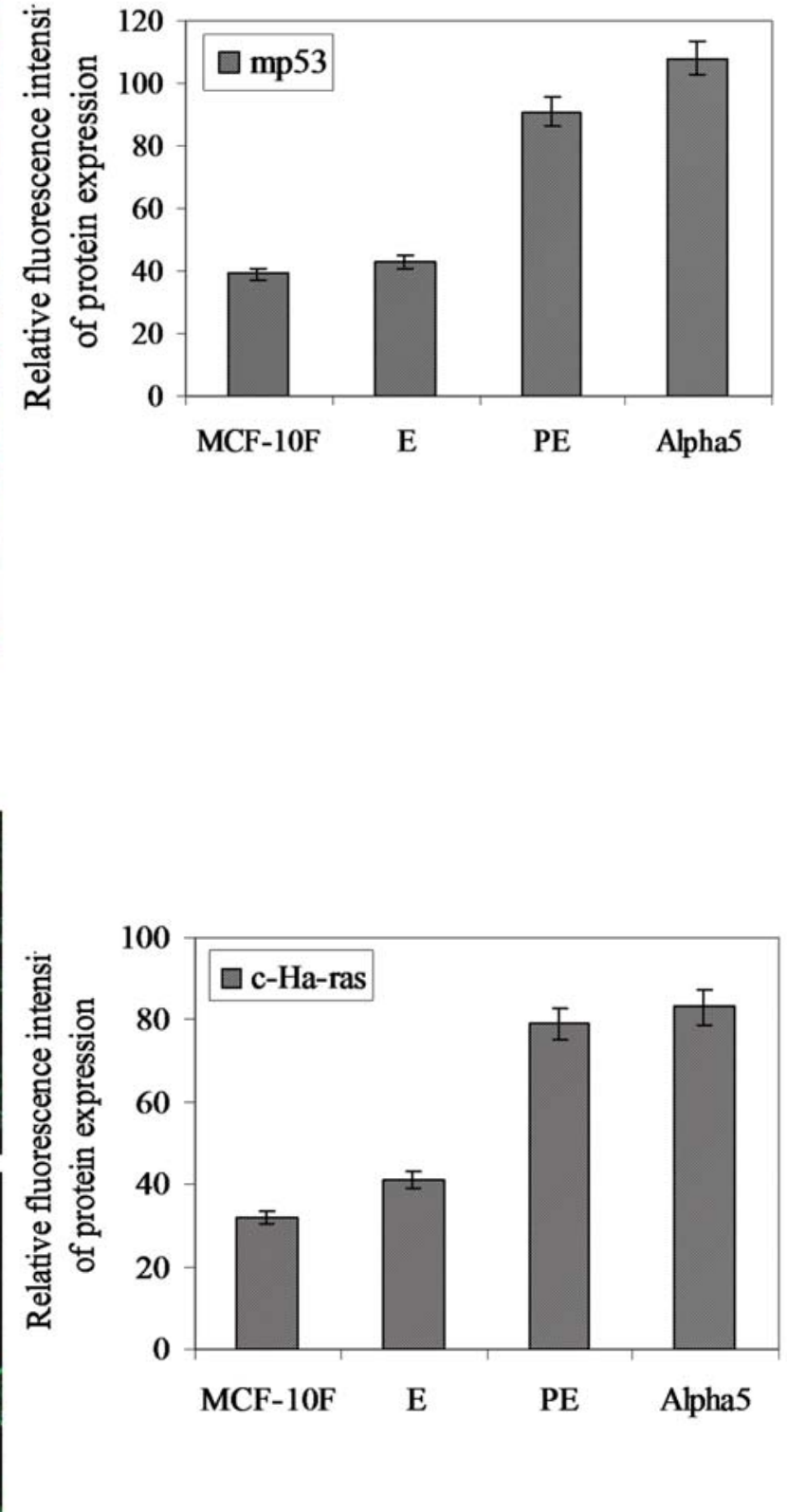

expression of the p53 tumor suppressor gene is found in breast cancer reviewed by Kiaris and Spandidos (18). Mutations in p53 gene have been found in $\sim 20-50 \%$ of human cancer $(12,14)$. Cancers with microsatellite instability have a low number of mutations in p53 tumor suppressor gene, and are associated with loss of apoptosis in ductal breast carcinomas $(58,59)$.

The marker used for $\mathrm{c}$-Ha-ras mapped in chromosome 11 p14.1 showed microsatellite instability in malathion and estrogen-treated cells. In the present study, loss of heterozygosity was found in parathion alone and combined with estrogen-treated cells, loss of heterozygosity in codon 12 in the estrogen alone and malathion alone-treated cells and micro- 


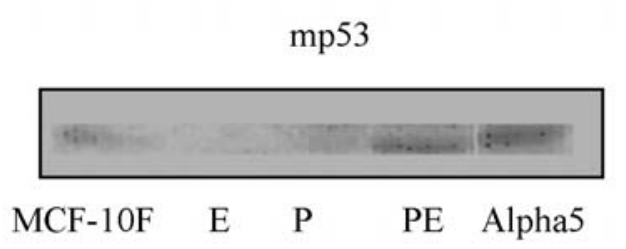

A

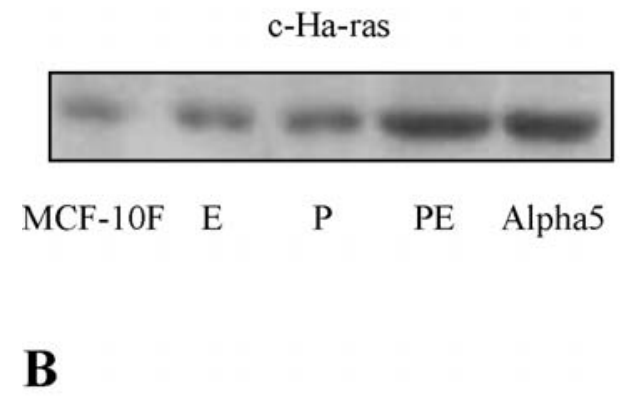

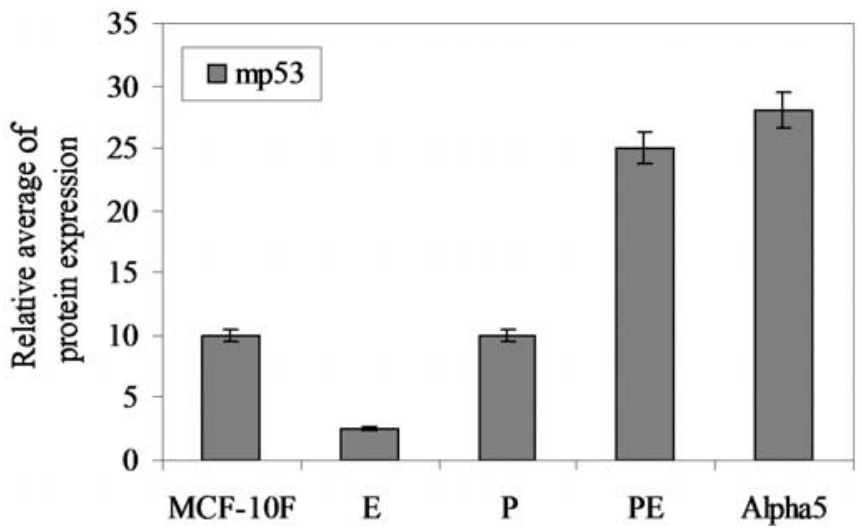

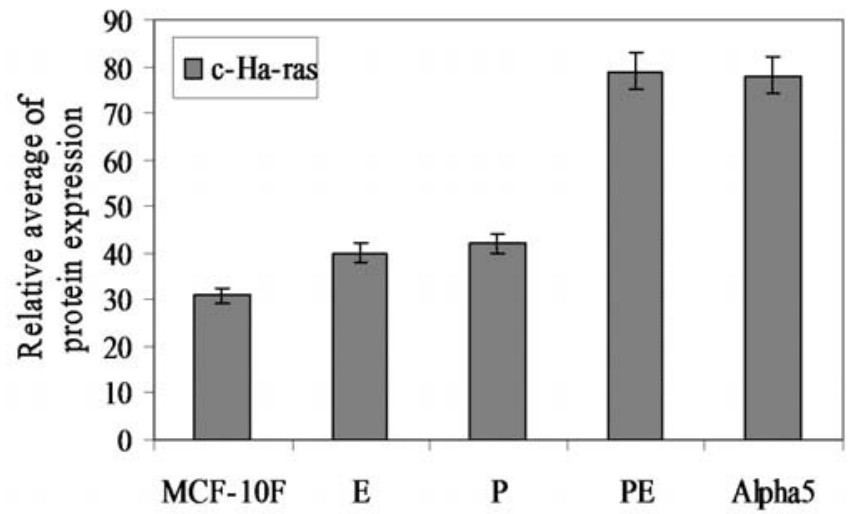

Figure 4. Image and quantification of protein expression with Western blot analysis of MCF-10F, P, E, PE and Alpha5 cells. (A) mp53 protein expression and (B) c-Ha-ras protein expression.
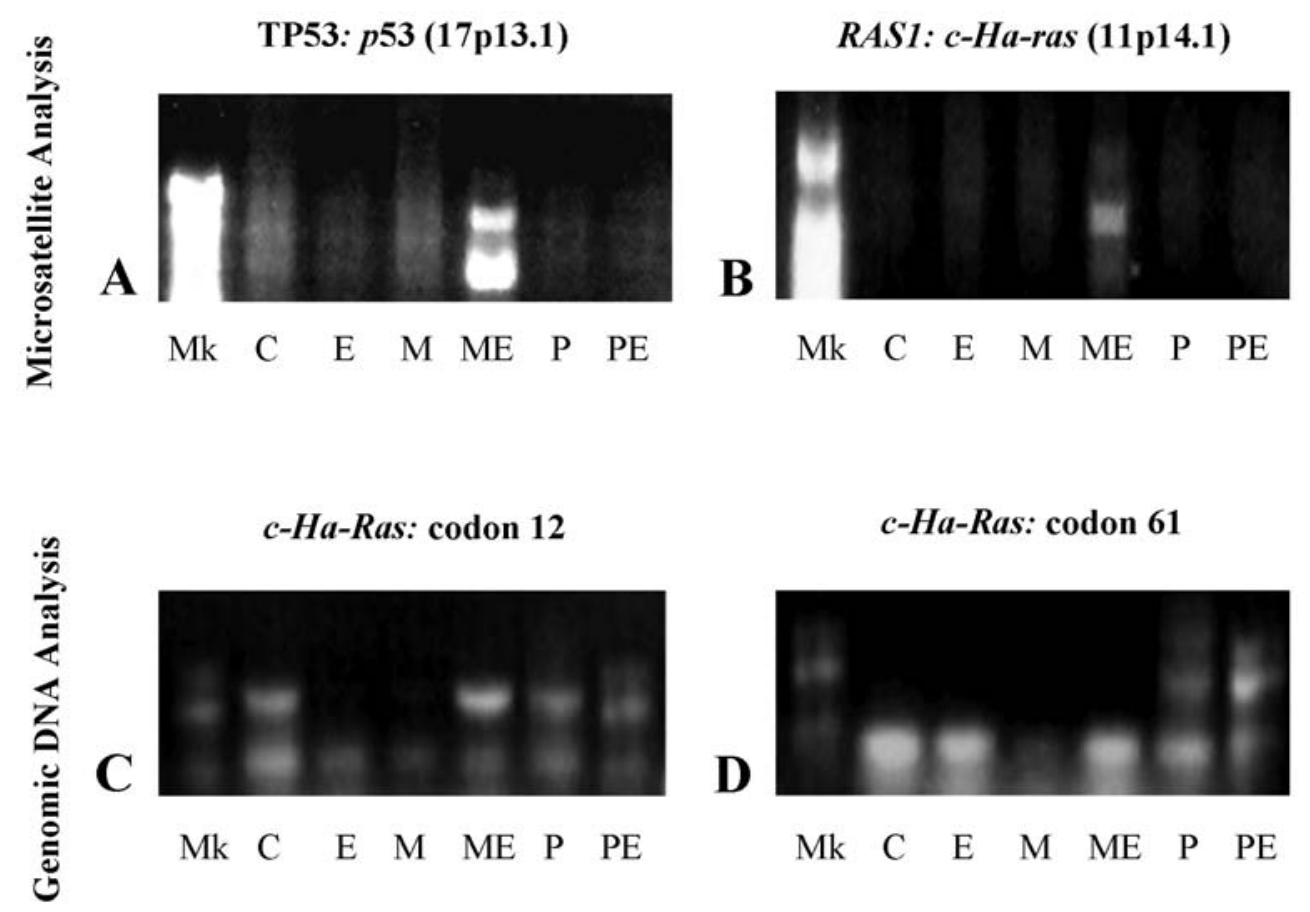

Figure 5. Microsatellite instability (MSI) and loss of heterozygosity (LOH) of MCF-10F, E, M, ME, P and PE of (A) mp53 tumor suppressor gene located in chromosome17 and (B) c-Ha-ras oncogene located in chromosome 11. Genomic DNA for c-Ha-ras codon (C) 12 and (D) 61. 
satellite instability in codon 61 of malathion in combination with estrogen-treated cells. We (60) previously reported $\mathrm{c}$-Haras allele loss and mutations in codons 12 and 61 induced by chemical carcinogens. We also previously determined the neoplastic phenotypes following treatment with benzo(a) pyrene (BP) and transfection with $c$-Ha-ras oncogene (61). Increased PCNA, Neu, ErbB-3 and cytokeratin 18 protein expression was observed in breast epithelial cells transformed with a chemical carcinogen and/or oncogene transfected that are not present in the MCF-10F.

Kiaris and Spandidos (18) indicated that overexpression of the Ras p21 protein can be found in different tissues according to numerous studies. Thus, breast tumors with higher Ras p21 protein expression than control was found in $60-70 \%$ of cases studied $(62,63)$. In most cases, the somatic missense Ras mutations found in cancer cells introduce amino acid substitutions at positions 12, 13 and 61 (64). The incidence of allelic imbalance at different chromosomal levels was reported in our previous observations involving overexpression of $c$-Ha-ras oncogene $(20,40)$. Oncogenic Ras proteins deregulate downstream effector pathways to confer the abnormal functional properties of cancer cells as deregulated cell growth and survival (64).

The specific genomic imbalances in microsatellite regions of specific genes seem to be important in cancer risk overall because tumor pathogenesis is in association of specific imbalances with disease prognosis and may be useful to apply therapy on specific targets. The knowledge of specific genetic changes and their biological consequences is critical to the understanding of breast cancer tumorigenesis. It can be concluded that the organophosphorous pesticide parathion and malathion induced malignant transformation of breast cells through genomic instability in the suppressor gene $p 53$ and the oncogene $\mathrm{c}$-Ha-ras, considered pivotal in the cancer process.

\section{Acknowledgements}

Fund support received from FONDECYT 1040300 (GMC) y 1080482 (GMC). The secretarial assistance of Danissa Barahona is greatly appreciated.

\section{References}

1. Blair A and Kazerouni N: Reactive chemicals and cancer. Cancer Causes Control 8: 473-490, 1997.

2. Falck F Jr, Ricci A Jr, Wolff MS, Godbold J and Deckers P: Pesticides and polychlorinated biphenyl residues in human breast lipids and their relation to breast cancer. Arch Environ Health 47: 143-146, 1992 .

3. National Cancer Institute: Bioassay of malathion for possible carcinogenicity. Carcinogenesis Technical Report Series No. 24. DHEW Publication No. (NIH) 78-84, 1978.

4. Reynolds P, Hurley SE, Gunier RB, Yerabati S, Quach T and Hertz A: Residential proximity to agricultural pesticide use and incidence of breast cancer in California, 1988-1997. Environ Health Perspect 113: 993-1000, 2005.

5. Andersen HR, Vinggaard AM, Rasmussen TH, Gjermandsen IM and Bonefeld-Jorgensen EC: Effects of currently used pesticides in assays for estrogenicity, androgenicity, and aromatase activity in vitro. Toxicol Appl Pharmacol 179: 1-12, 2002.

6. Bennett LM and Davis BJ: Identification of mammary carcinogens in rodent bioassays. Environ Mol Mutagen 39: 150-157, 2002

7. Brody JG and Rudel RA: Environmental pollutants and breast cancer. Environ Health Perspect 111: 1007-1019, 2003.
8. Henderson BE, Ross R and Bernstein L: Estrogens as a cause of human cancer: the Richard and Hinda Rosenthal Foundation award lecture. Cancer Res 48: 246-253, 1988.

9. Feigelson HS, Ross RK, Yu MC, Coetzee GA, Reichardt JK and Henderson BE: Genetic susceptibility to cancer from exogenous and endogenous exposures. J Cell Biochem (Suppl) 25: 15-22, 1996.

10. Bernstein L and Ross RK: Endogenous hormones and breast cancer risk. Epidemiol Rev 15: 48-65, 1993.

11. Pike MC, Spicer DV, Dahmoush L and Press MF: Estrogens, progestogens, normal breast cell proliferation, and breast cancer risk. Epidemiol Rev 15: 17-35, 1993.

12. Nigro JM, Baker SJ, Preisinger AC, et al: Mutations in p53 gene occur in diverse human tumor types. Nature 342: 705-708, 1989.

13. Levine AJ, Momand $\mathrm{J}$ and Finlay CA: The $p 53$ tumor suppressor gene. Nature 351: 453-456, 1991 .

14. Callahan R: p53 mutations, another breast cancer prognostic factor. J Natl Cancer Inst 84: 826-827, 1992

15. Russo J, Tahin Q, Lareef MH, Hu YF and Russo IH: Neoplastic transformation of human breast epithelial cells by estrogens and chemical carcinogens. Environ Mol Mutagen 39: 254-263, 2002.

16. Andersen TI, Holm R, Nesland JM, Heimdal KR, Ottestad L and Borresen AL: Prognostic significance of TP53 alterations in breast carcinoma. Br J Cancer 68: 540-548, 1993.

17. Smith ML and Fornace AJ Jr: Genomic instability and the role of p53 mutations in cancer cells. Curr Opin Oncol 7: 69-75, 1995.

18. Kiaris H and Spandidos DA: Mutations of ras genes in human tumours (Review). Int J Oncol 7: 413-421, 1995.

19. Zachos G and Spandidos DA: Expression of ras proto-oncogenes: regulation an implications in the development of human tumors. Crit Rev Oncol Hematol 26: 65-75, 1997.

20. Roy D, Calaf G and Hei TK: Allelic imbalance at 11p15.5-15.4 correlated with c-Ha-ras mutation during radiation-induced neoplastic transformation of human breast epithelial cells. Int $\mathbf{J}$ Cancer 103: 730-737, 2003.

21. Barbacid M: Oncogenes in human cancers and in chemically induced animal tumors. Prog Med Virol 32: 86-100, 1985.

22. Barbacid M: Ras genes. Annu Rev Biochem 56: 779-827, 1987.

23. Bos JL: Ras oncogenes in human cancer: a review. Cancer Res 49: 4682-4689, 1989.

24. Spandidos DA and Agnantis NJ: Human malignant tumours of the breast, as compared to their respective normal tissue, have elevated expression of the Harvey ras oncogene. Anticancer Res 4: 269-272, 1984

25. Matsumoto S, Minobe K, Utada Y, et al: Loss of heterozygosity at 3p24-p25 as a prognostic factor in breast cancer. Cancer Lett 152: 63-69, 2000

26. Tomlinson IP, Nicolai H, Solomon E and Bodmer WF: The frequency and mechanism of loss of heterozygosity on chromosome 11q in breast cancer. J Pathol 180: 38-43, 1996.

27. Iida A, Isobe R, Yoshimoto M, Kasumi F, Nakamura $Y$ and Emi M: Localization of a breast cancer tumour-suppressor gene to a 3-cM interval within chromosomal region $16 q 22 . \mathrm{Br} \mathrm{J}$ Cancer 75: 264-267, 1997.

28. Aaltonen LA, Peltomaki P, Leach FS, et al: Clues to the pathogenesis of familial colorectal cancer. Science 260: 812-816, 1993.

29. Thibodeau SN, Bren G and Schaid D: Microsatellite instability in cancer of the proximal colon. Science 260: 816-819, 1993.

30. Ionov Y, Peinado MA, Malkhosyan S, Shibata D and Perucho M: Ubiquitous somatic mutations in simple repeated sequences reveal a new mechanism for colonic carcinogenesis. Nature 363: 558-561, 1993.

31. Siah SP, Quinn DM, Bennett GD, Casey G, Flower RL, Suthers G and Rudzki Z: Microsatellite instability markers in breast cancer: a review and study showing MSI was not detected at 'BAT 25' and 'BAT 26' microsatellite markers in early-onset breast cancer. Breast Cancer Res Treat 60: 135-142, 2000.

32. Rennstam K, Baldetorp B, Kytola S, Tanner M and Isola J: Chromosomal rearrangements and oncogene amplification precede aneuploidization in the genetic evolution of breast cancer. Cancer Res 61: 1214-1219, 2001.

33. Soule HD, Maloney TM, Wolman SR, et al: Isolation and characterization of a spontaneously immortalized human breast epithelial cell line, MCF-10. Cancer Res 50: 6075-6086, 1990.

34. Calaf $\mathrm{G}$ and Russo J: Transformation of human breast epithelial cells by chemical carcinogens. Carcinogenesis 14: 483-492, 1993. 
35. Calaf GM and Hei TK: Establishment of a radiation- and estrogen-induced breast cancer model. Carcinogenesis 21: 769-776, 2000

36. Calaf $\mathrm{G}$ and Hei TK: Oncoprotein expression in human breast epithelial cells transformed by high-LET radiation. Int J Radiat Biol 77: 31-40, 2001.

37. Calaf GM: Susceptibility of human breast epithelial cells in vitro to hormones and drugs. Int J Oncol 28: 285-295, 2006.

38. Sambrook J, Fritsch EF and Maniatis T: Molecular Cloning. A Laboratory Manual. Cold Spring Harbor Laboratory Press, NY, 1989.

39. Gross-Bellard M, Oudet P and Chambon P: Isolation of highmolecular-weight DNA from mammalian cells. Eur J Biochem 36: 32-38, 1973

40. Roy D, Calaf G and Hei TK: Frequent allelic imbalance on chromosome 6 and 17 correlate with radiation-induced neoplastic transformation of human breast epithelial cells. Carcinogenesis 22: 1685-1692, 2001.

41. International Agency for Research on Cancer: Monographs on the evaluation of carcinogenic risks to humans. Vol. 30, IARC Scientific Publications, Lyon, pp102-129, 1983.

42. International Agency for Research on Cancer: Monographs on the evaluation of carcinogenic risks to humans. Vols. 1-42, IARC Scientific Publications, Lyon, 1987.

43. Tennant RW, Margolin BH, Shelby MD, et al: Prediction of chemical carcinogenicity in rodents from in vitro genetic toxicity assays. Science 236: 933-941, 1987.

44. Hour TC, Chen L and Lin JK: Comparative investigation on the mutagenicities of organophosphate, phthalimide, pyrethroid and carbamate insecticides by the Ames and lactam tests. Mutagenesis 13: 157-166, 1998

45. Amer SM, Fahmy MA, Aly FA and Farghaly AA: Cytogenetic studies on the effect of feeding mice with stored wheat grains treated with malathion. Mutat Res 513: 1-10, 2002.

46. Garaj-Vrhovac V and Zeljezic D: Cytogenetic monitoring of croatian population occupationally exposed to a complex mixture of pesticides. Toxicology 165: 153-162, 2001.

47. Garaj-Vrhovac V and Zeljezic D: Assessment of genome damage in a population of Croatian workers employed in pesticide production by chromosomal aberration analysis, micronucleus assay and Comet assay. J Appl Toxicol 22: 249-255, 2002.

48. Giri S, Prasad SB, Giri A and Sharma GD: Genotoxic effects of malathion: an organophosphorus insecticide, using three mammalian bioassays in vivo. Mutat Res 514: 223-231, 2002.

49. Prakash N, Narayana K, Murthy GS, Moudgal NR and Honnegowda: The effect of malathion, an organophosphate, on the plasma FSH, 17 beta-estradiol and progesterone concentrations and acetylcholinesterase activity and conception in dairy cattle. Vet Hum Toxicol 34: 116-119, 1992.

50. Asmathbanu I and Kaliwal BB: Temporal effect of methyl parathion on ovarian compensatory hypertrophy, follicular dynamics and estrous cycle in hemicastrated albino rats. J Basic Clin Physiol Pharmacol 8: 237-254, 1997.
51. Dhondup P and Kaliwal BB: Inhibition of ovarian compensatory hypertrophy by the administration of methyl parathion in hemicastrated albino rats. Reprod Toxicol 11: 77-84, 1997.

52. Gouda H and Sastry MS: Effect of 0,0-Dimethyl-0 phosphorothicate (sumithion) on reproductive performance in rats and oestrogenic activity in mice. Indian J Pharmacol 11: 287-292, 1979.

53. Bonner MR, Coble J, Blair A, Beane Freeman LE, Hoppin JA, Sandler DP and Alavanja MC: Malathion exposure and the incidence of cancer in the agricultural health study. Am J Epidemiol 166: 1023-1034, 2007.

54. Blasiak J, Jaloszynski P, Trzeciak A and Szyfter K: In vitro studies on the genotoxicity of the organophosphorus insecticide malathion and its two analogues. Mutat Res 445: 275-283, 1999.

55. Berkman CE, Quinn DA and Thompson CM: Interaction of acetylcholinesterase with the enantiomers of malaoxon and isomalathion. Chem Res Toxicol 6: 724-730, 1993.

56. Calaf GM and Roy D: Gene expression signature of parathiontransformed human breast epithelial cells. Int J Mol Med 19: 741-750, 2007.

57. Elsaleh H, Powell B, McCaul K, Grieu F, Grant R, Joseph D and Iacopetta B: P53 alteration and microsatellite instability have predictive value for survival benefit from chemotherapy in stage III colorectal carcinoma. Clin Cancer Res 7: 1343-1349, 2001.

58. Samowitz WS, Holden JA, Curtin K, et al: Inverse relationship between microsatellite instability and K-ras and p53 gene alterations in colon cancer. Am J Pathol 158: 1517-1524, 2001.

59. Mendez O, Manas S, Peinado, Fabra A, Escobedo A, Moreno A and Sierra A: Microsatellite instability is associated with the loss of apoptosis in ductal breast carcinomas. Breast Cancer Res Treat 65: 171-177, 2001.

60. Zhang PL, Calaf G and Russo J: Allele loss and point mutation in codons 12 and 61 of the c-Ha-ras oncogene in carcinogentransformed human breast epithelial cells. Mol Carcinog 9: 46-56, 1994.

61. Calaf GM, Alvarado ME and Hei TK: Oncoprotein expression and morphological phenotypes of human breast epithelial cells transformed by the c-Ha-ras oncogene. Oncol Rep 14: 885-893, 2005.

62. Enamoto T, Inoue M, Perantoni AO, Buzard GS, Miki H, Tanizawa $\mathrm{O}$ and Rice JM: K-ras activation in premalignant and malignant epithelial lesions of the human uterus. Cancer Res 51: 5308-5314, 1991.

63. Duggan BD, Felix JC, Muderspach LI, Tsao JL and Shibata DK: Early mutational activation on the c-Ki-ras oncogene in endometrial carcinoma. Cancer Res 54: 1604-1607, 1994.

64. Schubbert S, Shannon K and Bollag G: Hyperactive Ras in developmental disorders and cancer. Nat Rev Cancer 7: 295-308, 2007. 